\title{
Rates of dissolved organic carbon production and bacterial activity in the eastern North Atlantic Subtropical Gyre during summer
}

\author{
E. Teira ${ }^{1,5, *}$, M. J. Pazó ${ }^{1}$, M. Quevedo ${ }^{2}$, M. V. Fuentes ${ }^{3}$, F. X. Niell ${ }^{4}$, E. Fernández ${ }^{1}$ \\ ${ }^{1}$ Departamento de Ecología y Biología Animal, Universidad de Vigo, 36200 Vigo, Spain \\ ${ }^{2}$ Departamento de Biología de Organismos y Sistemas, Universidad de Oviedo, 33071 Oviedo, Spain \\ ${ }^{3}$ Departamento de Microbiología, and ${ }^{4}$ Departamento de Ecología, Universidad de Málaga, 29071 Málaga, Spain
}

${ }^{5}$ Present address: Royal Netherlands Institute for Sea Research (NIOZ), Department of Biological Oceanography, PO Box 59, 1790 AB Den Burg, The Netherlands

\begin{abstract}
Rates of particulate organic carbon (POC) production, dissolved organic carbon (DOC) production and bacterial production were measured at 8 stations in the eastern North Atlantic Subtropical Gyre during August 1998. The euphotic-depth-integrated POC rate was on average $27 \mathrm{mgC}$ $\mathrm{m}^{-2} \mathrm{~h}^{-1}$. The corresponding averaged integrated DOC production rate was $5 \mathrm{mg} \mathrm{C} \mathrm{m}^{-2} \mathrm{~h}^{-1}$, i.e. about $20 \%$ of the total primary production. No statistically significant relationship was found between the rates of POC and DOC production, suggesting that other processes besides phytoplankton exudation, such as cell lysis or protist grazing, could be implied in the release of dissolved organic materials to the oceanic environment. Euphotic-depth-integrated bacterial biomass and production were on average $214 \mathrm{mgC} \mathrm{m}^{-2}$ and $1.4 \mathrm{mgC} \mathrm{m}^{-2} \mathrm{~h}^{-1}$, respectively. The lack of correlation between the rates of DOC release and bacterial activity and a bacterial carbon demand (BCD, calculated using an estimated bacterial growth efficiency ranging from 11 to $18 \%$ ) in excess of DOC production suggested the existence of additional organic carbon sources (both allochthonous and/or autochthonous reservoirs), apart from in situ phytoplankton-derived DOC production, for the maintenance of bacterial activity in this region during summer 1998. This uncoupling between phytoplankton and bacterioplankton could partially explain the heterotrophic metabolic balance in this oligotrophic region during summer 1998.
\end{abstract}

KEY WORDS: Phytoplankton · Bacteria $\cdot$ Primary production $\cdot$ DOC production $\cdot$ Bacterial activity Coupling $\cdot$ North Atlantic Subtropical Gyre

\section{INTRODUCTION}

Microbial food webs, basically constituted by autotrophic pico- and nanoplankton, heterotrophic bacteria, virus and protozoa, predominate in oligotrophic stratified waters (e.g. Legendre \& Le Fèvre 1989, Kiørboe 1993, Legendre \& Rassoulzadegan 1995). In these systems, the dissolved organic pathway has been recognised as of great relevance for the transfer of matter through the planktonic food web (e.g. Azam et al. 1983, Legendre \& Le Fèvre 1995).
Given that most oceanic regions are oligotrophic (see Longhurst 1998), major fluxes of organic matter in the ocean are likely to be channelled through the dissolved pool into bacteria and the microbial loop (Azam 1998), making it necessary to invoke processes such as cell lysis (e.g. Bratbak et al. 1990, Agustí et al. 1998) or grazing (e.g. Jumars et al. 1989, Nagata \& Kirchman 1992), besides algal physiology, to explain the relatively large fluxes of recently photosynthesised organic matter to the dissolved organic carbon (DOC) pool. 
About $50 \%$ of daily photosynthetic production is utilised by heterotrophic bacteria (e.g. Ducklow \& Carlson 1992, Williams 2000); however, estimations of the magnitude of DOC fluxes through the microbial system are highly variable, representing from 2 to $1000 \%$ of primary production (Williams 2000). Most of these estimations derive from modelling or indirect approaches (e.g. from bacterial growth rate or microbial respiration measurements), and therefore are constrained by the uncertainty and difficulty concerning the conversion of microbial metabolism rates into geochemical mass units (C-based estimates). On the other hand, direct measurements of DOC production rates resulting from short incubations are very rare, especially in the oligotrophic ocean.

Direct determinations by Teira et al. (2001b), covering a wide productivity spectrum in the Atlantic Ocean, showed that the contribution of DOC production by microbial populations to primary production ranged between 4 and $42 \%$, being larger in oligotrophic waters. Unfortunately, the technique usually employed for direct measurement of DOC production rates by natural microbial populations is based on the release of labelled dissolved organic materials and does not distinguish between the DOC contributions of different processes within the microbial community. Nevertheless, the analysis of the relationship between the rates of particulate organic carbon (POC) and DOC production provides valuable information about changes in the relative magnitude of DOC fluxes along productivity gradients (Baines \& Pace 1991) as well as about the processes involved in the release of dissolved organic matter. A significant relationship between POC and DOC production rates would be expected if algal exudation were the main mechanism controlling DOC production. Moreover, if the recently released DOC, either through trophic or physiological processes, constituted the major supply of substrate for pelagic bacterial production, a positive relationship might be observed between rates of bacterial production and phytoplankton-derived in situ DOC production. The analysis of the relationship between bacterial production and phytoplankton-derived in situ DOC production allows the study of the coupling between bacteria and phytoplankton, whereby coupling represents the general dependence of bacteria on the DOC supplied by algae (see Morán et al. 2001).

Bacterial production in the open ocean depends not only on DOC supply, which largely originates from phytoplankton, but also on DOC composition (e.g. Kirchman 1990). Therefore, the production of semilabile phytoplankton-derived DOC, mainly associated with grazing and/or cell lysis, could induce uncoupling between the autotrophic and heterotrophic compartments (Blight et al. 1995), which would ultimately result in temporal offsets between the processes of DOC production and consumption. In this connection, recent studies have measured rates of bacterial carbon utilisation exceeding rates of primary production in oligotrophic environments (e.g. Hansell et al. 1995, del Giorgio et al. 1997).

Within this context, we measured rates of DOC production by microbial populations as well as bacterial biomass and production in the oligotrophic eastern North Atlantic Subtropical Gyre during August 1998, with the aims of (1) investigating the spatial variability in the fraction of recently photosynthesised carbon contributed by the DOC pool to the total amount of carbon photoassimilated by phytoplankton, commonly defined as percentage of extracellular release (PER), (2) determining which processes or variables are relevant in the control of DOC production in this region, and (3) establishing the extent of coupling between phytoplankton and bacteria in relation to the carbon fluxes through the microbial community.

\section{MATERIALS AND METHODS}

Sampling region. The rate of DOC production by microbial populations as well as bacterial abundance and production rates were measured at 8 stations (biological stations) along 2 transects (A and B) during Cruise 'Azores-1' in the eastern North Atlantic Subtropical Gyre in August 1998 (Fig. 1). Vertical profiles of temperature, salinity and fluorescence were obtained at the biological stations and at additional (CTD) stations with a Neil Brown Mark III CTD attached to a rosette sampler equipped with 101 Niskin bottles. Photosynthetically available radiation (PAR) was measured with a light PAR sensor. Rates of POC,

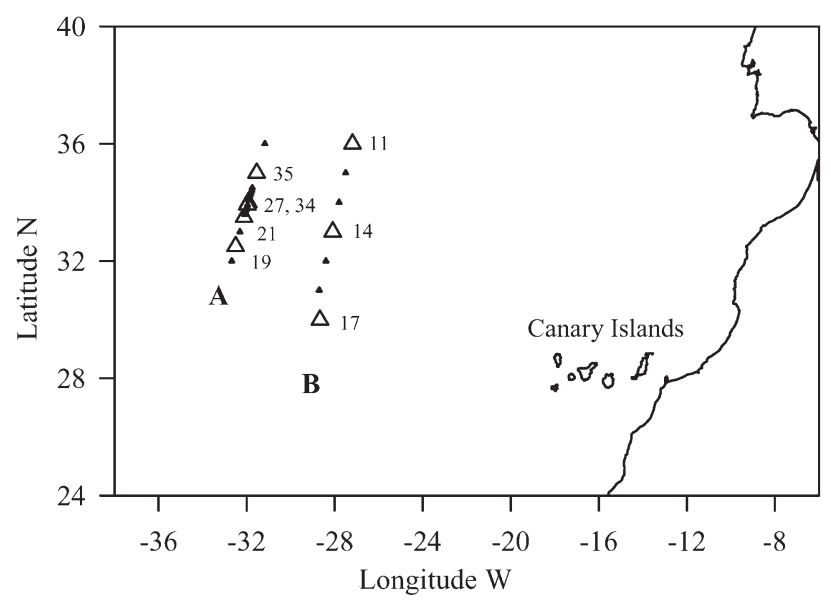

Fig. 1. Map of sampling stations visited in August 1998. ( $\triangle$ ) Biological stations, and ( $\mathbf{A}$ CTD stations along Transects A and B 
DOC and bacterial production, as well as bacterial and microzooplankton abundance and biomass were measured only at biological stations.

POC and DOC production rates. At each station, five $30 \mathrm{ml}$ samples were collected at 5 selected depths from the euphotic layer, inoculated with $1480 \mathrm{kBq}(40 \mu \mathrm{Ci})$ of $\mathrm{NaH}^{14} \mathrm{CO}_{3}$ and incubated in an on-deck incubator that simulated the irradiance experienced by the cells at the original sampling depths. Incubations were run for $2 \mathrm{~h}$ to minimise concurrent bacterial consumption of recently released DOC during the incubation period (see review in Fogg 1983). The bottles were kept refrigerated by pumping surface seawater into the incubator. Previous studies did not show statistically significant differences between primary production estimates derived from on-deck and in situ incubation procedures (Joint et al. 1993). After the incubation period, two 8 to $10 \mathrm{ml}$ subsamples were drawn from each bottle and filtered by gravity through Millipore APFF glass-fibre filters (approximate pore size $0.45 \mu \mathrm{m})$. Filtrates were acidified with 40 to $75 \mu \mathrm{l}$ of $\mathrm{HCl} 50 \%$ (until a pH value around 2 was reached) and bubbled with $\mathrm{CO}_{2}$-free air for $12 \mathrm{~h}$. Filters were decontaminated by exposure to concentrated $\mathrm{HCl}$ fumes for $12 \mathrm{~h}$. Scintillation cocktail was then added to both filters and filtrates. Duplicate blank tests were run in parallel by inoculating and immediately processing $0.2 \mu \mathrm{m}$-filtered seawater in the same way. This blank test was used as control for ${ }^{14} \mathrm{C}$ stock purity and to check the efficiency of the decontamination process (Berman \& Holm-Hansen 1974, Mague et al. 1980). This control is recommended since the zero-time values for filtrates are always significantly higher than blank values due to some interaction with particulate matter during the few seconds of exposure after inoculation (see Mague et al. 1980). Radioactivity was measured on both filters (POC production, POCP) and filtrates (DOC production, DOCP) with an LKB $\beta$-scintillation counter. Quenching corrections were made using an external standard. Filtrate blank values were on average $187 \pm 22 \mathrm{SE} \mathrm{dpm}$ for all the experiments. The mean $( \pm \mathrm{SE})$ variation coefficient for the replicate measurements of POC and DOC production rates was $19 \pm 1$ and $32 \pm 2 \%$, respectively.

Daily POCP rates were calculated from hourly rates using the equation of Straskraba \& Gnauck (1985). Daily DOCP rates were estimated assuming that either the release of dissolved material occurs only during the light period ( $\mathrm{DOCP}_{\text {light }}$ ), which would be expected if DOCP were closely related to the photosynthetic process, or that DOC release takes place at the same rate during the light and dark periods $\left(\mathrm{DOCP}_{24 \mathrm{~h}}\right)$, which may be reasonable if trophicrelated processes (grazing, cell lysis) were mainly implicated in the release of dissolved materials. There- fore, the actual rate of daily DOCP must lie within these 2 extreme estimations.

Two recent papers have explicitly questioned the adequacy of using glass-fibre filters for measuring POC and DOC production (Karl et al. 1998, Morán et al. 1999) because of ${ }^{14} \mathrm{C}$-DOC adsorption onto these type of filters. Consequently, the DOC production rates reported here should be considered as conservative estimations. However, the use of different type of filters (e.g. membrane filters) has not been proved to render more accurate estimations of POC and DOC production rates (Karl et al. 1998, Morán et al. 1999). The high capacity of glass-fibre filters to retain picoeukaryotes has frequently been reported (e.g. Gasol \& Morán 1999). Accordingly, we are confident that the dissolved fraction can include only bacteria, virus and colloidal particles.

Daily gross primary production (GPP) was calculated as the sum of POCP and $\mathrm{DOCP}_{\text {light }}$. Daily net primary production (NPP) was estimated as in Marañón et al. (2000), assuming that dark respiratory losses represent $20 \%$ of daily POCP $\left(\mathrm{NPP}=\mathrm{POCP} \cdot 0.8+\mathrm{DOCP}_{\text {light }}\right)$.

Bacterial abundance. Using an epifluoresce microscope, bacterial abundance was measured by direct counts of samples collected on black polycarbonate filters (Porter \& Feig 1980). Samples were fixed with glutaraldehyde (final concentration $2.5 \% \mathrm{vol} / \mathrm{vol}$ ) and kept in the dark at $4^{\circ} \mathrm{C}$ until further processing ashore. Subsamples $(2 \mathrm{ml})$ were taken and stained with DAPI (4'-6-dianimo-2-penylindone) for $5 \mathrm{~min}$ in the dark, and then filtered through $0.2 \mu \mathrm{m}, 25 \mathrm{~mm}$ diameter polycarbonate filters under a low vacuum pressure ( $<150 \mathrm{~mm} \mathrm{Hg}$ ). The filters were assembled on a slide with low fluorescence oil, and kept in the dark until visualisation. Bacterial enumeration was performed for a minimum of 10 randomly selected areas. The samples were observed with a Nikon microscope equipped with a $100 \mathrm{~W}$ mercury lamp for epifluorescence illumination, and a block of UV-2B filters for UV light. Counting was made using a UV light at $\times 1000$ magnification. Bacterial numbers $Z$ (bacteria $\mathrm{ml}^{-1}$ ) were obtained from the following expression:

$$
Z=176.71 \times N /(A \times D \times V)
$$

where 176.71 is the effective filter area, $N$ represents the average number of micro-organisms counted in each sample, $A$ is the counting area $\left(\mathrm{mm}^{2}\right), D$ the sample dilution, and $V$ the filtered volume. Cell abundance was transformed to bacterial carbon biomass (BB) using the average cell density reported by Christian \& Karl (1994) of 0.12 pg C $\mathrm{\mu m}^{-3}$. Average bacterial biovolume (BV) was assumed to be the value calculated by Kuipers et al. (2000) for the same region and season. These authors reported an average early

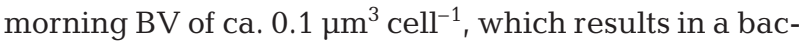


terial carbon content of $12 \mathrm{fg} \mathrm{C} \mathrm{cell}^{-1}$. The average bacterial carbon content estimated in this study lies within the range of values reported by Bode et al. (2001) for oceanic waters near the Canary Islands in summer 1998 (17 fg C cell $\left.{ }^{-1}\right)$, by Zubkov et al. (2000) for the Atlantic Ocean $\left(7 \mathrm{fg} \mathrm{C}\right.$ cell $\left.^{-1}\right)$ and by Carlson et al. (1996) for the Sargasso Sea (4 to $7 \mathrm{fg} \mathrm{C} \mathrm{cell}^{-1}$ ), and is very similar to the average bacterial carbon content calculated from direct measurements by Fukuda et al. (1998) for oceanic environments.

Bacterial production. Bacterial production was estimated from $\left[{ }^{3} \mathrm{H}\right]$ thymidine incorporation rates. Three water subsamples $(20 \mathrm{ml})$ and 2 controls containing $1 \%(\mathrm{vol} / \mathrm{vol})$ formaldehyde were incubated in the dark at in situ temperature for 60 min with $10 \mathrm{nM}$ $\left[{ }^{3} \mathrm{H}\right.$-methyl] thymidine (70 to $85 \mathrm{Ci} \mathrm{mmol}^{-1}$ ). After incubation, an equal volume of ice-cold $5 \%$ (wt/vol) trichloroacetic acid was added to each subsample. After $5 \mathrm{~min}$ on ice, the samples were filtered through $0.2 \mu \mathrm{m}$ pore-size cellulose ester membrane filters with a vacuum pressure of $<150 \mathrm{~mm} \mathrm{Hg}$ and rinsed 5 times with $1 \mathrm{ml}$ of ice-cold $5 \%$ (wt/vol) trichloroacetic acid. The filters were then dried at room temperature and placed in scintillation vials and $1 \mathrm{ml}$ of ethyl acetate was added to dissolve the filters; 15 min later, $10 \mathrm{ml}$ of scintillation liquid was added to each vial and radioactivity was measured on an LKB $\beta$-scintillation counter. Bacterial production (BP), in cell $\mathrm{l}^{-1} \mathrm{~h}^{-1}$, was estimated from $\left[{ }^{3} \mathrm{H}\right]$ thymidine (Td) incorporation using the following equation:

$$
\mathrm{BP}=\mathrm{nmol} \mathrm{Td} \times \mathrm{CF} / \mathrm{IT}
$$

where $\mathrm{mol} \mathrm{Td}=\mathrm{dpm} \times(\mathrm{SA})^{-1} \times 4.5 \times 10^{-13}, \mathrm{SA}$ is the specific activity of thymidine $\left(\mathrm{Ci} \mathrm{mol}^{-1}\right)$ and $4.5 \times 10^{-13}$ represents $\mathrm{Ci} \mathrm{dpm}^{-1}$. The conversion factor (CF) used was $1.18 \times 10^{18} \mathrm{cell} \mathrm{mol}^{-1} \mathrm{Td}$ (Ducklow 1993), a conservative value within the 'theoretical' range proposed by Fuhrman \& Azam $(1980,1982)$. It represents incubation time. We used an estimated bacterial carbon content of $12 \mathrm{fg} \mathrm{C} \mathrm{cell}^{-1}$, as described in earlier subsection 'Bacterial abundance'. The variation coefficient for the BP measurements was always lower than $20 \%$.

The bacterial growth efficiency (BGE) was estimated from the water temperature using the empirical model of Rivkin \& Legendre (2002). Bacterial carbon demand (BCD) was calculated from volumetric rates of BP and the estimated $\mathrm{BGE}(\mathrm{BCD}=\mathrm{BP} / \mathrm{BGE})$. Bacterial respiration (BR) was estimated as the difference between $\mathrm{BCD}$ and BP. The average BGE derived was 0.15 , and ranged between 0.11 and 0.18. BGE measurements reported in the literature for the Sargasso Sea range from 0.04 to 0.19 (Hansell et al. 1995, Carlson \& Ducklow 1996).

Microzooplankton biomass. To assess the composition, abundance and biomass of microzooplankton, at the biological stations (except at Stns 19 and 21) water samples were drawn from 2 to 4 selected depths. Samples were fixed in pre-added acid Lugol solution (5\% final concentration) and stored at $5^{\circ} \mathrm{C}$ in the dark. Preceding analysis, the whole samples were settled in $500 \mathrm{ml}$ test tubes for at least $6 \mathrm{~d}$. The upper $450 \mathrm{ml}$ of each sample were gently siphoned off and discarded, and the remainder of the samples allowed to settle for a minimum of $20 \mathrm{~h}$ in $25 \mathrm{~mm} \varnothing$ Utermöhl chambers. The samples were then analysed under a phasecontrast Olympus IMT-2 inverted microscope at magnifications of $\times 150, \times 400$ or $\times 600$. To account for the possibility of cell losses during the sedimentation process, a correction factor (i.e. 1.3 for small dinoflagellates and no correction for small ciliates and larger protists) was obtained from the average number of cells remaining in the discarded portions of 5 samples. To estimate microzooplankton biomass, linear dimensions of dinoflagellates and ciliates were measured with an image-analysis system attached to the inverted microscope and converted to volumes assuming simple geometric shapes, as recommended by Hillebrand et al. (1999). Carbon content was estimated from volume using $0.19 \mathrm{pg} \mathrm{C} \mathrm{mm}^{-3}$ for Lugol-preserved ciliates (Putt \& Stoecker 1989) and according to the method of Menden-Deuer \& Lessard (2000) for dinoflagellates. Although photosynthetic dinoflagellates are known to perform phagotrophy or extracellular digestion (Gaines \& Elbrächter 1987), only phagotrophic or mixotrophic genera according to Lessard \& Swift (1986) and Gaines \& Elbrächter (1987) were considered.

Euphotic zone integration. Euphotic-zone-integrated values of bacterial biomass and POC, DOC and bacterial production were obtained by trapezoidal integration of the volumetric data down to the depth of $1 \%$ surface incident irradiance. Euphotic zone depth ranged from 80 to $120 \mathrm{~m}$.

\section{RESULTS}

\section{Thermohaline and chlorophyll a fluorescence distribution}

The thermal structure of the water column in both transects (A and B) shows the prevalence of strong vertical stratification (Fig. 2). The northward sloping of the 16 to $18^{\circ} \mathrm{C}$ isotherms, and specifically the location where the $16^{\circ} \mathrm{C}$ isotherm reaches $200 \mathrm{~m}$, are valuable indicators of the position of the subtropical frontal boundary (Gould 1985, Fernández \& Pingree 1996) which separates warmer, more haline, Western Atlantic water from colder and less saline Eastern Atlantic water. In this study, the subtropical frontal (STF) boundary was located between 34 and $35^{\circ} \mathrm{N}$ in 

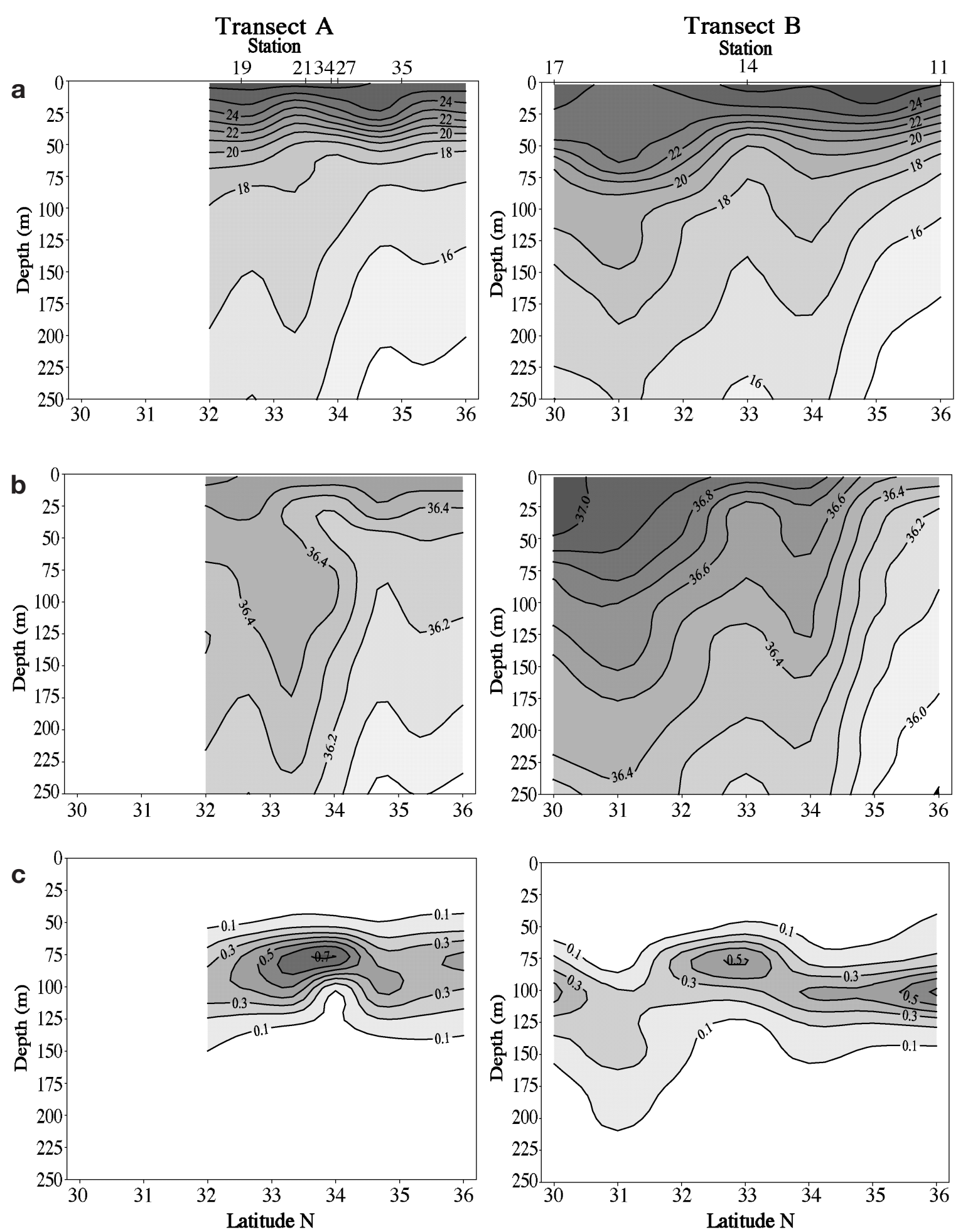

Fig. 2. Vertical distribution of (a) temperature $\left({ }^{\circ} \mathrm{C}\right)$, (b) salinity, and (c) chlorophyll a fluorescence (arbitrary units) along Transects A and B. Numbers on upper axis indicate biological stations

both transects. The vertical distribution of salinity (Fig. 2b) also distinguishes the STF boundary. Uplifting of isotherms and isohalines at Stn 14 indicates the presence of colder and fresher water in the sub- tropical side of the frontal zone. A more detailed description of the large and meso-scale hydrographic variability during this cruise has been made by Pérez et al. (2003). 


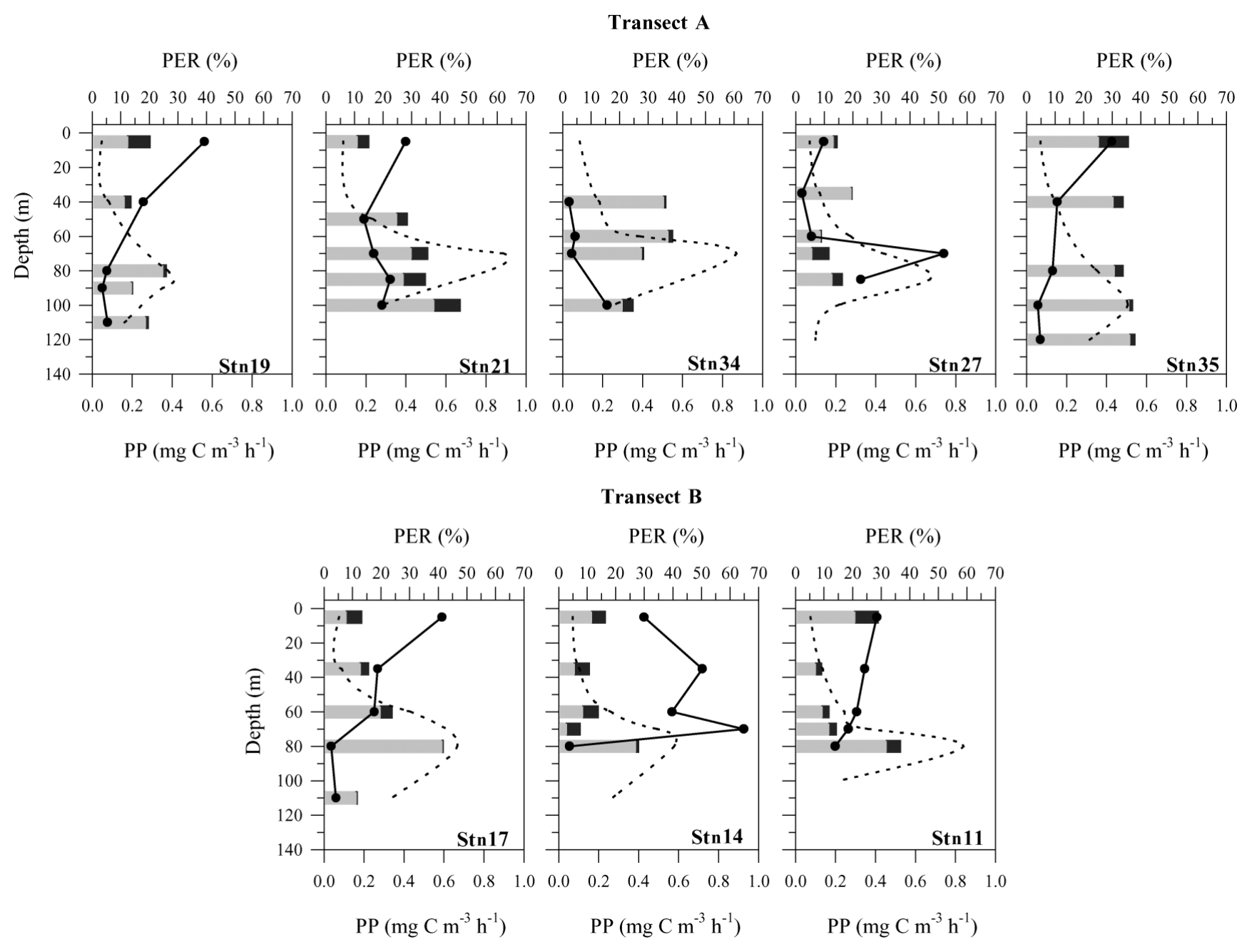

Fig. 3. Vertical profiles of primary production (PP) of POC (grey bars) and DOC (black bars) at biological stations along Transects A and B. Superimposed continuous and dotted lines: percentage of extracellular release (PER) and chlorophyll a fluorescence, respectively; fluorescence scale (arbitrary units) is the same as that for PP

Table 1. Daily depth-integrated variables and biological stations sampled in North Atlantic Subtropical Gyre during summer 1998. See 'Materials and methods' for calculations. POCP: particulate organic carbon production; $\mathrm{DOCP}_{\text {light }}, \mathrm{DOCP}_{24 \mathrm{~h}}$ : dissolved organic production during light period only and during light plus dark periods, respectively; NPP: net primary production; $\mathrm{PER}_{\text {light }}, \mathrm{PER}_{24 \mathrm{~h}}$ : percent extracellular release during light period only and during light plus dark periods, respectively; BB: bacterial carbon biomass; BP: bacterial production; BCD: bacterial carbon demand

\begin{tabular}{|c|c|c|c|c|c|c|c|c|c|}
\hline \multirow[t]{2}{*}{ Variable } & \multicolumn{3}{|c|}{ Transect A, Stns; } & \multicolumn{5}{|c|}{ Transect B, Stns; } & \multirow[t]{2}{*}{ Mean $\pm \mathrm{SE}$} \\
\hline & 11 & 14 & 17 & 19 & 21 & 27 & 34 & 35 & \\
\hline POCP $\left(\mathrm{mg} \mathrm{C} \mathrm{m}^{-2} \mathrm{~d}^{-1}\right)$ & 195 & 129 & 483 & 329 & 452 & 216 & & 715 & $360 \pm 72$ \\
\hline $\mathrm{DOCP}_{\text {light }}\left(\mathrm{mg} \mathrm{C} \mathrm{m}^{-2} \mathrm{~d}^{-1}\right)$ & 59 & 77 & 58 & 59 & 101 & 29 & & 96 & $69 \pm 9$ \\
\hline $\mathrm{DOCP}_{24 \mathrm{~h}}\left(\mathrm{mgC} \mathrm{m} \mathrm{Cl}^{-2} \mathrm{~d}^{-1}\right)$ & 106 & 137 & 102 & 106 & 180 & 51 & & 171 & $122 \pm 16$ \\
\hline $\mathrm{NPP}\left(\mathrm{mg} \mathrm{C} \mathrm{m} \mathrm{m}^{-2} \mathrm{~d}^{-1}\right)$ & 215 & 180 & 444 & 322 & 463 & 202 & & 668 & $356 \pm 63$ \\
\hline $\mathrm{PER}_{\text {light }}(\%)$ & 23 & 37 & 11 & 15 & 18 & 12 & & 12 & $18 \pm 3$ \\
\hline $\mathrm{PER}_{24 \mathrm{~h}}(\%)$ & 42 & 67 & 19 & 27 & 32 & 20 & & 21 & $33 \pm 6$ \\
\hline $\mathrm{BB}\left(\mathrm{mg} \mathrm{C} \mathrm{m} \mathrm{m}^{-2}\right)$ & 202 & 209 & 230 & 239 & 192 & 188 & 207 & 247 & $214 \pm 7$ \\
\hline 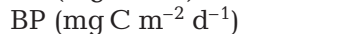 & 32 & 14 & 8 & 48 & 61 & 29 & 30 & 46 & $33 \pm 6$ \\
\hline $\mathrm{BCD}\left(\mathrm{mg} \mathrm{C} \mathrm{m}^{-2} \mathrm{~d}^{-1}\right)$ & 227 & 104 & 57 & 303 & 385 & 186 & 261 & 251 & $222 \pm 35$ \\
\hline BP:NPP & 0.15 & 0.08 & 0.02 & 0.15 & 0.13 & 0.14 & & 0.07 & $0.11 \pm 0.02$ \\
\hline $\mathrm{BCD}: \mathrm{DOCP}_{\text {light }}$ & 3.85 & 1.35 & 0.98 & 5.14 & 3.81 & 6.41 & & 2.61 & $3.45 \pm 0.69$ \\
\hline $\mathrm{BCD}: \mathrm{DOCP}_{24 \mathrm{~h}}$ & 2.14 & 0.76 & 0.56 & 2.86 & 2.14 & 3.65 & & 1.47 & $1.94 \pm 0.39$ \\
\hline
\end{tabular}


The lowest chlorophyll a fluorescence values $(<0.1$ arbitrary units) were found in the upper water column (about $40 \mathrm{~m}$ ) and in deeper waters (<0.2 arbitrary units below 100 to $150 \mathrm{~m}$ ) along both transects (Fig. 2c). Chlorophyll a fluorescence showed a maximum at around $100 \mathrm{~m}$ in both sections, which became slightly shallower in the proximity of the STF in Transect A and around Stn 14 in Transect B. The maximum values of chlorophyll a fluorescence were found in the western transect close to the southern boundary of the STF, between Stns 19 and 21. Typical values of chlorophyll a concentration reported previously for the studied area we lower than $0.1 \mathrm{mg} \mathrm{m}^{-3}$ in surface waters, and between 0.2 and $0.4 \mathrm{mg} \mathrm{m}^{-3}$ in the subsurface chlorophyll a maximum (Marañón et al. 2000, Serret et al. 2001).

\section{POC and DOC production rates}

Rates of POC production were not always related to chlorophyll a fluorescence (Fig. 3). The depth of the maximum POC production rate was variable, mainly in Transect A, ranging from $35 \mathrm{~m}$ at Stn 27 to $120 \mathrm{~m}$ at Stn 35, whereas the location of the chlorophyll a fluorescence maximum varied between 70 and $100 \mathrm{~m}$. Rates of POC production ranged from 0.04 to $0.59 \mathrm{mg} \mathrm{C}$ $\mathrm{m}^{-3} \mathrm{~h}^{-1}$, averaging (mean $\pm \mathrm{SE}$ ) $0.28 \pm 0.02 \mathrm{mgC} \mathrm{m}^{-3}$ $\mathrm{h}^{-1}$. Rates of DOC production varied from 0.01 to $0.15 \mathrm{mg} \mathrm{C} \mathrm{m}^{-3} \mathrm{~h}^{-1}$, averaging $0.05 \pm 0.01 \mathrm{mg} \mathrm{C} \mathrm{m}^{-3} \mathrm{~h}^{-1}$. We did not find any general pattern for the vertical distribution of DOCP rates in this oligotrophic region. Maximum values were measured either in surface waters (Stns 19, 35, 17 and 11) or close to the deep chlorophyll a fluorescence maximum (Stns 21, 27, 34 and 14). As a consequence of the lack of coupling between the rates of POC and DOC production, the vertical distribution of the fraction of recently photosynthesised carbon contributed by the DOC pool to the total amount of carbon photoassimilated by phytoplankton (i.e. the percentage of extracellular release, PER) showed different patterns between stations. At those stations where maximum rates of DOC production were found at the surface, the PER profile followed an almost continuous decreasing trend with increasing depth. In contrast, at stations where maximum DOC production rates were measured near the chlorophyll $a$ fluorescence maximum, a more irregular pattern was observed, with higher PER values generally found in deeper waters. PER values estimated from hourly rates varied from 2 to $65 \%$, and averaged $19 \pm 2$ (SE) \%.

Daily euphotic-depth-integrated POCP rates ranged from 129 to $715 \mathrm{mgC} \mathrm{m}^{-2} \mathrm{~d}^{-1}$ (Table 1). The highest value was measured at Stn 35, located on the northern margin of the STF. Integrated POC production values were similar to those measured by Fernández \& Pingree (1996) in the same region during March 1992. Their primary production measurements ranged from 0.3 to $1.0 \mathrm{~g} \mathrm{C} \mathrm{m}^{-2} \mathrm{~d}^{-1}$, with higher (0.8 to $1.0 \mathrm{~g} \mathrm{C} \mathrm{m}^{-2} \mathrm{~d}^{-1}$ ) values associated with the frontal area. We only found a clear productivity enhancement in relation to the frontal area in the northern extreme of the STF boundary in the western transect (Stn 35). Our measurements (with the exception of Stn 35) fit well with previous primary production estimates in the NE subtropical Atlantic region which ranged between 0.1 and $0.4 \mathrm{~g} \mathrm{C}$ $\mathrm{m}^{-2} \mathrm{~d}^{-1}$ (Frazel \& Berberian 1990, Jochem \& Zeitzschel 1993, Fernández \& Pingree 1996, Marañón et al. 2000, Robinson et al. 2002). Daily euphotic-depthintegrated DOC production rates, estimated considering both that the release of dissolved materials occurs only during the light period $\left(\mathrm{DOCP}_{\text {light }}\right)$, and that DOC release takes place also throughout the dark period $\left(\mathrm{DOCP}_{24 \mathrm{~h}}\right)$, were less variable than POC production rates (Table 1). It is important to note that different PER values are obtained depending on whether DOC production rates integrated for the light period or for $24 \mathrm{~h}$ are used. This must be taken into account when comparative analysis are made between previously published results and the data presented in this paper. Depth-integrated DOC production estimates for the light period were of the same magnitude as those obtained by Thomas (1971) in the western Sargasso Sea (data from 1 station) and Choi (1972) in the Gulf Stream (data from 3 stations), where the corresponding PER values ranged from 13 to $34 \%$. To our knowledge, the measurements in the present study are the first DOC production measurements reported for the oligotrophic North East Atlantic Subtropical Gyre.

The great variability in PER values in the present study contrasts highly with the low and almost constant PER values $(<10 \%)$ obtained in both exponentially growing cultures and productive conditions (Nagata 2000 and references therein, Teira et al. 2001a).

Statistically significant relationships between POC and DOC production were not obtained either for volumetric $(\mathrm{p}=0.436, \mathrm{n}=39)$ or integrated $(\mathrm{p}=0.338$, $\mathrm{n}=7$ ) rates. A possible explanation for this lack of correlation between POC and DOC production could be the predominance of trophic processes leading to cell breakage (grazing, lysis) over physiological processes (exudation) in the release of dissolved organic materials.

In order to assess the potential trophic control of DOC production in this investigation, we compared the measured rates of extracellular release with microzooplankton biomass values obtained from those depths were both variables were concurrently determined. Microzooplankton abundance and biomass ranged respectively from 1.2 to $3.3 \times 10^{3}$ cell ml $\mathrm{ml}^{-1}$ and from 0.40 to $2.53 \mathrm{mg} \mathrm{C} \mathrm{m}^{-3}$, being generally higher in 

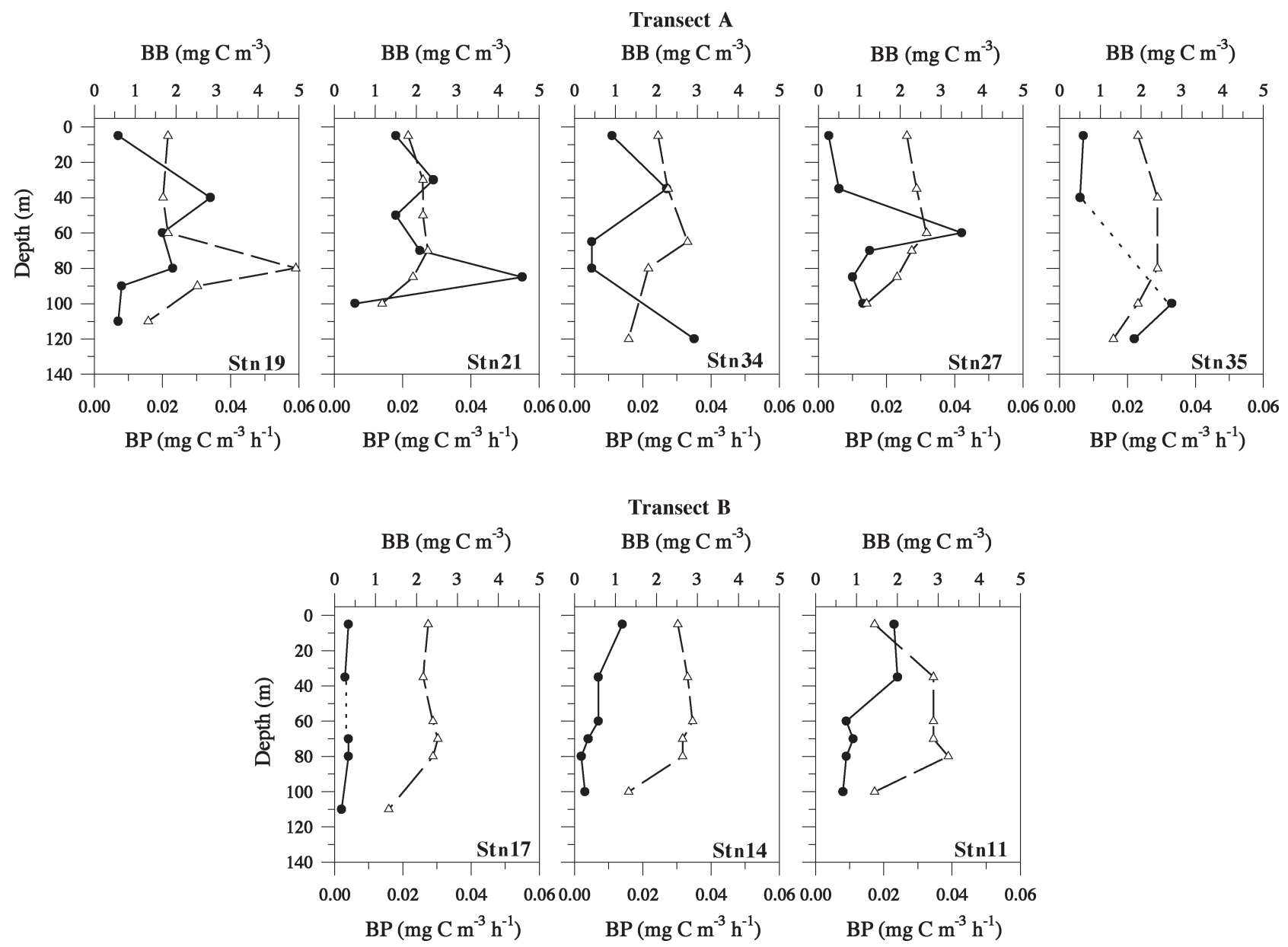

Fig. 4. Vertical profiles of bacterial biomass (BB) (dashed line) and production rates (BP) (continuous line) at biological stations along Transects A and B

the northern side of the STF boundary (Stns 11 and 35). About $74 \%$ of the total biomass corresponded to the $>20 \mu \mathrm{m}$ microzooplankton size fraction, with a relatively higher contribution of small organisms (38\%) at Stn 35. Ciliates were less abundant than dinoflagellates, and represented on average $62 \%$ of the total microzooplankton biomass. We failed to find any statistically significant relationship between DOC production rates and microzooplankton biomass, either between total microzooplankton biomass and DOC production or between ciliate or dinoflagellate biomass and DOC production ( $\mathrm{p}>0.7, \mathrm{n}=14)$.

\section{Bacterial biomass and production}

Bacterial abundance and biomass ranged between 1 and $4 \times 10^{5}$ cells $\mathrm{ml}^{-1}$ and between 1.2 and $4.9 \mathrm{mg} \mathrm{C}$ $\mathrm{m}^{-3}$, respectively (Fig. 4). The bacterial abundance measured in this investigation, was well within the range of typical values reported for comparable waters. It was very similar to that reported by Zubkov et al. (1998) for oligotrophic regions in the Atlantic Ocean during fall 1996, to the average values of Harrison et al. (2001) for the North Atlantic Subtropical Gyral East province (derived from 2 cruises conducted in September-October 1992 and May-June 1993), and to the data of Bode et al. (2001) for the nearby Canary Islands region $\left(1\right.$ to $6 \times 10^{5}$ cells $\left.\mathrm{ml}^{-1}\right)$. However, our measurements were, on average, about 2 -fold lower than the values reported by González et al. (2001) for the subtropical North Atlantic in August 1998 and by Kuipers et al. (2000) for the same region in August 1996. Although the bacterial abundances reported by González et al. (2001) and ourselves were obtained on the same cruise, caution must be taken in comparing the two sets of data, since different methods for bacterial quantification were used - flow cytometry by González et al. (2001) and microscopic observation in the present study (see Sieracki et al. 1995). 
The vertical distribution of bacterial biomass was fairly homogeneous, with no marked maximum, except at Stn 19 where a maximum value of $4.9 \mathrm{mg} \mathrm{C} \mathrm{m}^{-3}$ was measured at $80 \mathrm{~m}$. A general decreasing trend of bacterial biomass was observed with increasing depth. Average bacterial biomass was $2.2 \pm 0.1(\mathrm{SE}) \mathrm{mg} \mathrm{C} \mathrm{m}^{-3}$. Bacterial production varied from 0.13 to $2.98 \mathrm{nmol}$ thymidine $\mathrm{m}^{-3} \mathrm{~h}^{-1}$, and from 0.002 to $0.055 \mathrm{mgC} \mathrm{m}^{-3}$ $\mathrm{h}^{-1}$, averaging $0.014 \pm 0.002$ (SE) $\mathrm{mgC} \mathrm{m}^{-3} \mathrm{~h}^{-1}$ (Fig. 4). Maximum values were observed at between 60 and $120 \mathrm{~m}$ in Transect $\mathrm{A}$, whereas maximum rates were found at the surface in Transect B. Specific growth rate of the bacterial assemblage, calculated as the natural logarithm of the relative increase in bacterial carbon biomass, ranged from 0.017 to $0.523 \mathrm{~d}^{-1}$, corresponding to generation times from 57.8 to $1.9 \mathrm{~d}$. These rates are similar to those reported by Bode et al. (2001) for oligotrophic waters around the Canary Islands (0.064 to $0.437 \mathrm{~d}^{-1}$ ), but higher than those found by Zubkov et al. (2000) in the subtropical North Atlantic during September 1995 and April 1997 (between 0.04 and $0.17 \mathrm{~d}^{-1}$ ), and by Carlson et al. (1996) in the NW Sargasso Sea from 1991 to 1994 (mean seasonal values from 0.057 in autumn to 0.096 in spring).

Daily euphotic-depth-integrated values of BB and BP are given in Table 1 . Whereas BB remained almost constant in the region, BP varied between 8 and $61 \mathrm{mg} \mathrm{C} \mathrm{m}^{-2} \mathrm{~d}^{-1}$, with minimum rates at Stns 14 and 17

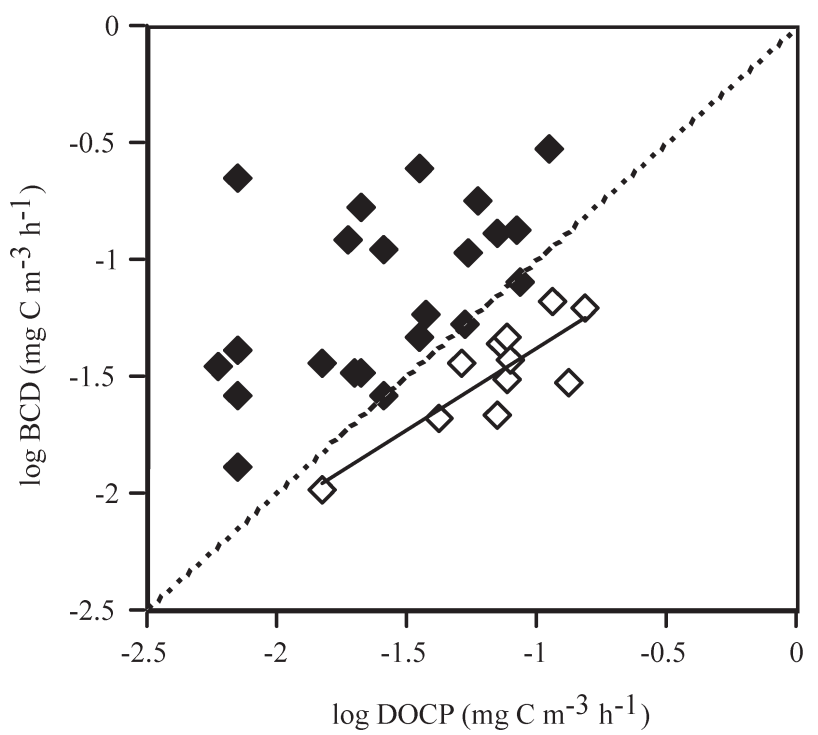

Fig. 5. Log-log relationship between bacterial carbon demand (BCD) and DOC production (DOCP) obtained using estimated bacterial growth efficiency (BGE) ranging from 0.11 to 0.18 (Rivkin \& Legendre 2002). Dashed line: line of Slope 1; continuous line: regression line obtained using data below line of Slope 1 (data below line of Slope 1 represented by open symbols) located in the southern end of Transect B. On average, BP represented $11 \%$ of net primary production NPP (Table 1). Comparisons between bacterial stocks and production rates are highly constrained by the methodological approach as well as the conversion factors used. The averaged integrated bacterial biomass reported here was very similar to that reported by Zubkov et al. (2000) (ca. 0.15 to $0.20 \mathrm{~g} \mathrm{C} \mathrm{m}^{-2}$ ) in the subtropical North Atlantic during September 1995. All these estimations are lower than the euphotic zone average $\left(0.5\right.$ to $\left.2 \mathrm{~g} \mathrm{C} \mathrm{m}^{-2}\right)$ across a range of oceanic systems given in a recent review by Ducklow (2000), even considering that all his biomass estimations were based on a conversion factor of $20 \mathrm{fg} \mathrm{C} \mathrm{Cell}^{-1}$. The average BP rate obtained in this study (Table 1) was 3-fold higher than the rate reported by Zubkov et al. (2000) during September 1995 for the subtropical North Atlantic, and very similar to the mean value given by Carlson et al. (1996) for the Sargasso Sea and by González et al. (2001) for the same region during April 1999. The mean BP:NPP ratio was in the lower extreme of the global average (0.1 to 0.2) calculated for the oceans (Ducklow 2000).

No significant relationship was found between BB or BP and DOC production ( $\mathrm{p}>0.2, \mathrm{n}=34$ ), which suggests that recently phytoplankton-derived DOC production was not the main carbon source for bacterial metabolism in this oligotrophic region at the time of

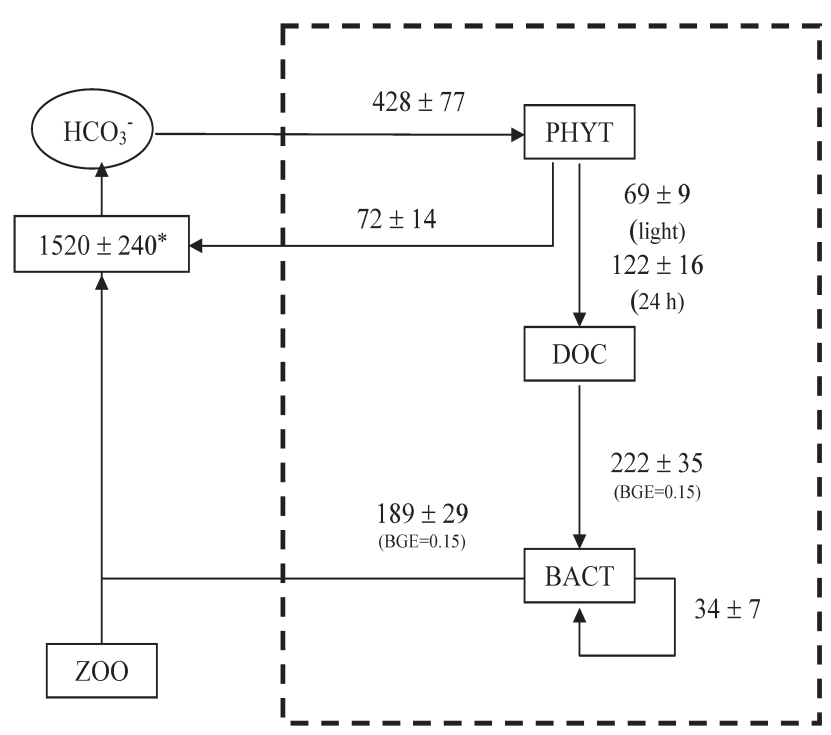

Fig. 6. Carbon flow through microbial community in euphotic zone of the eastern North Atlantic Subtropical Gyre in summer. Fluxes expressed in $\mathrm{mgC} \mathrm{m} \mathrm{m}^{-2} \mathrm{~d}^{-1}$; calculations and conversion factors are explained in 'Materials and methods'. PHYT: phytoplankton; BACT: bacteria; BGE: bacterial growth efficiency; ZOO: zooplankton; *microbial respiration

(González et al. 2001) 
the survey. Also, no correlation was observed between $\mathrm{BB}$ or BP and microzooplankton biomass $(\mathrm{p}>0.1$, $\mathrm{n}=15$ ). Using the BGE derived form the model by Rivkin \& Legendre (2002) (see 'Materials and methods'), the bacterial carbon demand (BCD) globally exceeded DOC production (Fig. 5) and no statistical relationship was observed between the 2 variables $(\mathrm{p}=0.816, \mathrm{n}=34)$, indicating that phytoplanktonderived in situ DOC production by the microbial community was not enough to fulfil bacterial metabolism. However, a significant relationship between BCD and DOC production was found when considering only data below the line of Slope $1(\log B C D=0.70 \log$ DOCP $-0.67, \mathrm{r}^{2}=0.69, \mathrm{p}=0.0016, \mathrm{n}=11$ ). Integrated BCD was, on average, 2- to $>3$-fold higher than integrated DOC production when DOCP is assumed to take place during $24 \mathrm{~h}$ or during the light period, respectively (Table 1 ). There were 2 stations which had a BCD:DOCP ${ }_{24 \mathrm{~h}}$ ratio $<1$, indicating that in those cases, concurrent DOCP by microbial populations could be sufficient to maintain bacterial activity. However, this does not necessarily imply that bacteria and phytoplankton are coupled. We analysed the relationship between volumetric BCD and DOCP using only data from these 2 stations (14 and 17), and found no significant relationship between the 2 variables, arising from the fact that 3 out of 9 data points were located above the line of Slope 1. Therefore, the degree of coupling between bacteria and phytoplankton showed great variability with depth, although we did not observe any general pattern: data points below or above line of Slope 1 originated either from surface or from deeper waters.

\section{Carbon flow through microplankton in eastern North Atlantic Subtropical Gyre during summer}

Carbon fluxes through the microplankton community in the euphotic zone of the North Atlantic Subtropical Gyre during August 1998 were computed using all the rates quantified and estimated in this study, and the averaged $\mathrm{O}_{2}$ community respiration rate measured by González et al. (2001) in the same region during the same cruise (Fig. 6). The average community respiration rate given by González et al. (2001) was transformed to carbon units using a respiratory quotient equal to 0.8 (Robinson et al. 2002). BCD was calculated using an estimated BGE, as explained described in 'Materials and methods'. Bacterial respiration (mean $\pm \mathrm{SE}$ ), derived from the estimated $\mathrm{BCD}$, amounted on average to $189 \pm 29 \mathrm{mg} \mathrm{C} \mathrm{m}^{-2} \mathrm{~d}^{-1}$, representing $12 \pm 2 \%$ of the total microbial respiration. Mean $( \pm$ SE) phytoplankton respiration $(86 \pm 15 \mathrm{mgC}$ $\mathrm{m}^{-2} \mathrm{~d}^{-1}$ ) was assumed to be $20 \%$ of gross primary pro- duction (for details see 'Materials and methods'), and contributed $6 \pm 1 \%$ to total microbial community respiration.

The net balance between primary production and microbial community respiration was heterotrophic, and the DOC flux was clearly insufficient to fuel bacterial growth and respiration. The average PER (mean $\pm \mathrm{SE}$ ) varied between $18 \pm 3$ and $33 \pm 6 \%$ of total primary production, depending on whether a constant DOC release during the light period or during a $24 \mathrm{~h}$ period is considered. Phytoplankton-derived in situ DOC production (mean $\pm \mathrm{SE}$ ) would meet on average between $30 \pm 10$ and $50 \pm 10 \%$ of BCD. The need for additional inputs of organic matter to sustain heterotrophic bacterial activity implies an uncoupling between phytoplankton and bacterioplankton dynamics. The ratio between $\mathrm{BCD}$ and NPP averaged $0.72 \pm 0.13$ $( \pm \mathrm{SE})$, and was very similar to that $(0.72 \pm 0.11)$ obtained using the empirical model of Hoppe et al. (2002), who related the BCD:PP ratio directly to the meridional profile of the water temperature.

\section{DISCUSSION}

\section{Potential mechanisms of DOC production in the oligotrophic North Atlantic Subtropical Gyre}

It is now well established that although most of the DOC in the ocean ultimately derives from phytoplankton, there are several mechanisms besides phytoplankton exudation involved in the release of dissolved organic substances to the marine environment (see review of Nagata 2000). Although it is not clear yet what the actual mechanism of phytoplankton exudation (Fogg 1983, Bjørnsen 1988) is, a highly significant relationship between DOC production and photosynthetic rates would be predictable if phytoplankton exudation were the main process whereby DOC is being released from phytoplankton cells.

We failed to detect any relationship between POC and DOC production rates, using either volumetric or integrated data. This result contrasts with most of the previous attempts to relate both variables (e.g. Baines \& Pace 1991, Morán et al. 2001, Teira et al. 2001a). What all these studies had in common was that they included data mainly from productive systems, with rates of POC production ranging from $>0.1$ to $>45 \mathrm{mgC}$ $\mathrm{m}^{-3} \mathrm{~h}^{-1}$, while the rates of particulate production measured in the present investigation varied between only 0.04 and $0.59 \mathrm{mg} \mathrm{C} \mathrm{m}^{-3} \mathrm{~h}^{-1}$. One possible explanation for the lack of correlation between POC and DOC production could be a higher error associated with the measurement of the abovementioned rates in lowproduction environments. However, we discarded this 
possibility as the mean variation coefficient for replicate DOC production measurements calculated for a productive coastal system using the same methodological protocol (Teira et al. 2001a) was not significantly different from that calculated in this study (Student's $t$-test, $\mathrm{p}=0.057$ ). As suggested in 'Results', the lack of correlation between the rates of carbon fixation and extracellular release in oligotrophic conditions can be interpreted as a predominance of trophic versus physiological processes as sources of DOC in the water column. Earlier (Teira et al. 2001b), we showed that in oligotrophic environments a higher percentage of PER variability could be better explained by changes in phytoplankton size-structure than by the magnitude of carbon incorporation rates. Important fluxes of photosynthesised materials to the dissolved organic matter (DOM) pool as a result of processes such as phytoplankton cell lysis (Brussaard et al. 1995, Gobler et al. 1997, Agustí et al. 1998) or grazing by protozoa (Nagata 2000 and references therein), have been recently related to stratified oligotrophic environments in which small primary producers form the bulk of the photosynthetic organisms and the microbial trophic pathway dominates. Predominance of small phytoplankton is a regular pattern observed in the North Atlantic Subtropical Gyre (Marañón et al. 2000). Size-fractionated primary production measurements conducted during the Azores-1 cruise along a latitudinal transect between 30 and $38^{\circ} \mathrm{N}$ and centred at $22^{\circ} \mathrm{W}$ showed that picophytoplankton accounted for $>55 \%$ of the total primary production. In order to investigate the potential role of trophic processes in the release of dissolved materials in the upper water column we first analysed the relationship between DOC production rates and microzooplankton biomass and did not find a significant relationship between the 2 variables. Conceptually, rates of DOC release might be related to protist grazing rates instead of biomass. Although concurrent measurements of microzooplankton grazing and DOC production rates were not carried out in this study, very high rates of microzooplankton grazing (about $80 \%$ of daily primary production) were measured in the area by Quevedo \& Anadón (2001), which supports the potentially relevant role of grazing activity on DOC production expected for oligotrophic environments. On the other hand, rates of cell lysis and DOC production could not be compared, as the former were not measured in this study. Agustí et al. (2001) estimated DOC excretion rates derived from phytoplankton cell lysis in the eastern subtropical North Atlantic as about $30 \%$ of net primary production, which is within the PER range obtained in this study (20 to $67 \%$ ) assuming that DOC release occurs over $24 \mathrm{~h}$.

All these considerations suggest that the major supply of substrate for pelagic bacterial production in the oligotrophic subtropical NE Atlantic Ocean might be trophic processes rather than direct algal exudation. If algal exudation were the main source of DOC for bacteria, a positive relationship between BP and DOC production rates should be observed (Søndergaard et al. 1995). No significant relationships were found between either BB or BP and DOC production rates, which further support the hypothesis of the trophic control of phytoplankton-derived DOC production. Moreover, protist grazing on heterotrophic bacteria (e.g. FerrierPagès et al. 1998, Kuipers \& Witte 2000), bacterial cell lysis by virus infection (e.g. Fuhrman \& Noble 1995, Thingstad 2000), and direct release of DOM from bacteria (Stoderegger \& Herndl 1998) would lead to the presence of bacterial-derived DOM in the water column, thus contributing to the DOM cycling within the microbial food web.

\section{Uncoupling between phytoplankton and bacteria in the upper subtropical North Atlantic Ocean during summer}

As already stated, we use here the term 'coupling' to represent the dependence of bacteria on the concurrent phytoplankton-DOC release by microbial populations. Therefore, only concomitant and accurate determinations of bacterial production and dissolved organic carbon production will allow a proper analysis of the degree of coupling between phytoplankton and bacteria. The results presented in this paper clearly indicate uncoupling between phytoplankton and bacterioplankton at most of the studied stations in the oligotrophic subtropical North Atlantic during summer 1998.

Comparison of $\mathrm{BCD}$ with $\mathrm{DOC}$ production rates (Fig. 5), revealed no significant relationship between the 2 variables, and (using an estimated BGE of 0.11 to 0.18 ) daily euphotic-depth-integrated DOC production accounted only for 30 to $50 \%$ of the corresponding average daily BCD (Fig. 6, Table 1). Although uncoupling between bacteria and phytoplankton can be concluded from the data in Figs. 5 \& 6 , it is essential to stress that whereas a negative balance between DOC production and consumption does imply uncoupling between bacteria and phytoplankton, the converse is not necessarily true.

The clear uncoupling between bacteria and phytoplankton derived from the lack of correlation between both variables (as shown in Fig. 5) does not depend on methodological assumptions; however, the negative balance between phytoplankton-derived DOC production and subsequent bacterial consumption shown in Fig. 6 was highly dependent on the conversion factors used for the estimation of $\mathrm{BP}$ and $\mathrm{BR}$, and therefore 
conclusions based on this balance must be made with caution, given that BR varies by up to 1 order of magnitude when using the theoretic range of BGE for open-ocean regions (0.03 to 0.27 ). BCD is usually estimated from BP and an assumed BGE value due to the technical difficulties associated with the measurement of bacterial respiration. Such an assumed value is either taken from the literature or derived by application of an empirical model. The model of del Giorgio \& Cole (1998) allows BR to be derived directly from BP rates, whereas a recent model of Rivkin \& Legendre (2002) directly relates BGE to temperature. When we applied the model by del Giorgio \& Cole (1998) we obtained a mean BGE of 0.03 , which represents the lower extreme of the theoretical range for open-ocean regions (del Giorgio \& Cole 2000). Consequently, we used the temperature-BGE relationship of Rivkin \& Legendre (2002), which gives more conservative values for BR. In addition, the uncertainty concerning the transformation of BP rates to carbon units (which depends both on the thymidine conversion factor, TCF, and on bacterial carbon content, BCC) must also be considered. In this regard we also used rather conservative conversion factors compared with those most commonly used in the literature (for TCF, $2.2 \times$ $10^{18} \mathrm{cells} \mathrm{mol}^{-1}$, and for BCC, $20 \mathrm{fg} \mathrm{C}^{\mathrm{C} e l l}{ }^{-1}$ ). The relatively low mean BP:NPP (0.11) obtained in the present study may result from an underestimation of the BP rates as a consequence of the conservative conversion factors employed.

The uncertainties involved in the estimation of BR do not allow us to conclude from our results whether the stations studied in the subtropical NE Atlantic showed a net heterotrophic, a balanced or a net autotrophic production/respiration (P:R) balance at the time this study was conducted. Thus, in situ phytoplanktonderived DOC production would be sufficient to support bacterial consumption if a BGE > 0.27 were assumed, although such a value would be higher than the average value (median 0.09, mean $\pm \mathrm{SD}=0.15 \pm 0.12$ ) reported for open-ocean systems (del Giorgio \& Cole 2000). Also, the average daily-integrated BCD would represent $>100 \%$ of NPP using a BGE $<0.10$. This would lead to a net heterotrophic P:R balance, as independently derived for the same region and sampling period by (González et al. 2001) from measurements of community respiration estimated from in vitro changes in $\mathrm{O}_{2}$ concentration after $24 \mathrm{~h}$ incubations. A net heterotrophic P:R on short timescales within the North Atlantic Subtropical Gyre was also reported by Duarte et al. (2001) and Serret et al. (2001), who measured rates of community respiration similar to those obtained by González et al. (2001). A detailed and rigorous analysis of in vitro determinations of plankton community respiration conducted by Robinson et al.
(2002) in the eastern Atlantic showed that the unexpected respiration rates, in excess of gross production, found in the picoautotroph-dominated oligotrophic regions of the Atlantic Ocean was consistent with measured and estimated autotrophic and heterotrophic activity; Robinson et al. (2002) concluded that the community respiration data were not grossly overestimated. Hansell et al. (1995) also found that rates of DOC mineralization represented between 100 and $220 \%$ of the primary production of the Sargasso Sea between September 1993 and April 1994. These imbalances clearly indicate an allochthonous supply and/or an autochthonous reservoir of organic carbon (del Giorgio et al. 1997, Duarte \& Agustí 1998, Duarte et al. 1999, 2001, Robinson et al. 2002), and thus could partially result from a temporal delay in the consumption by bacteria of previously released phytoplanktonderived DOC.

Independent of this metabolic balance controversy, our results suggest that to assume that the DOC flux equals total BCD is not necessarily valid when phytoplankton and bacterioplankton dynamics are not coupled. Although several studies focussing on the relationship between phytoplankton and bacterioplankton have shown a close coupling between the release of DOC and BP rates (e.g. Lancelot \& Billen 1984, Panzenböck et al. 2000, Morán et al. 2001), other studies have found that the in situ production of phytoplankton-derived DOC would be insufficient to support the heterotrophic population (e.g. Williams \& Yentsch 1976, Bode et al. 2001).

A possible explanation for the bacterial-phytoplankton uncoupling could be the accumulation of DOC during a previous productive period. Several investigations have observed temporal shifts between autotrophic and heterotrophic processes, as reflected by a net heterotrophic $\mathrm{P}: \mathrm{R}$ balance following periods of high primary production (e.g. Blight et al. 1995, Sherr \& Sherr 1996, Serret et al. 1999). The production and accumulation of semilabile DOC, deriving mainly from grazing or cell lysis, would act as a transient carbon reservoir which could sustain microheterotrophic respiration after the decline of the productive period (Blight et al. 1995). Williams (1995) suggested that dissolved inorganic nitrogen limitation of heterotrophic bacteria consuming DOM with high $\mathrm{C}: \mathrm{N}$ ratios could explain the accumulation of DOC during summer in the North Atlantic Ocean. The seasonal accumulation of semilabile DOC in the surface layer of the ocean is at present well documented (Carlson et al. 1994, Yamanaka \& Tajika 1997, Hansell \& Carlson 1998) and has been reported by Doval et al. (2001), who measured an accumulation of semilabile DOC in the upper $100 \mathrm{~m}$ of $16.8 \mathrm{~g} \mathrm{C} \mathrm{m}^{-2}$ in the Azores Front region during August 1998. This seasonal DOC excess could have 
acted as an autochthonous reservoir and, at least partially, have supported the excess of BCD over DOC production measured in this study. If we assume that $\mathrm{BP}$ rate and BGE remain constant over time, the turnover of the accumulated carbon would be, on average, $106 \pm 27$ (SE) d.

Uncoupling between bacteria and phytoplankton could also result from an allochthonous supply of organic carbon. The potential heterotrophic carbon sources in the eastern Atlantic Ocean have been exhaustively discussed by Robinson et al. (2002). Duarte et al. (2001) proposed lateral inputs from the productive upwelling areas in the NW African coast as a potentially relevant allochthonous carbon source in the subtropical NE Atlantic. Other allochthonous sources of organic matter that should also be taken into consideration would be atmospheric deposition of DOM through marine rain (Willey et al. 2000) or dust storms (Cornell et al. 1995, Bory \& Newton 2000), and photochemical production of labile DOC from more refractory molecules (e.g. Mopper et al. 1991, Bushaw et al. 1996, Moran \& Zepp 2000). Robinson et al. (2002) estimated that photodegradation would account for only 1 to $2 \%$ of the bacterial carbon demand in the eastern Atlantic.

In conclusion, the present study shows a great variability in PER values in the subtropical NE Atlantic Ocean during the summer period that is hypothesised to be related to the predominant role of trophic processes (grazing, cell lysis) as sources of DOC in the oligotrophic ocean. The lack of correlation between the rates of phytoplankton-derived DOC release and bacterial activity during the summer in this oceanic region reflects the uncoupling between both microbial compartments and implies additional organic carbon sources, apart from in situ phytoplankton-derived DOC production, for the maintenance of bacterial activity.

Acknowledgements. This work was supported by EU contract CANIGO (MAS3CT960060). E.T. was funded by a PFPI fellowship from the Ministerio de Ciencia y Tecnología (Spain). We are indebted to the captain and crew of BIO 'Hespérides' as well as to all the colleagues on board during the Cruise Azores-1.

\section{LITERATURE CITED}

Agustí S, Satta MP, Mura MP, Benavent E (1998) Dissolved esterase activity as a tracer of phytoplankton lysis: evidence of high phytoplankton lysis rates in the NW Mediterranean. Limnol Oceanogr 43:1836-1849

Agustí S, Duarte CM, Vaqué D, Hein M, Gasol JM, Vidal M (2001) Food web structure and elemental (C, N and P) fluxes in the Eastern tropical North Atlantic. Deep-Sea Res Part II 48:2295-2321

Azam F (1998) Microbial control of oceanic carbon flux: the plot thickens. Science 280:694-696
Azam F, Fenchel T, Field FG, Gray JS, Meyer-Reil LA, Thingstad F (1983) The ecological role of water-column microbes in the sea. Mar Ecol Prog Ser 23:99-106

Baines SB, Pace ML (1991) The production of dissolved organic matter by phytoplankton and its importance to bacteria: patterns across marine and freshwater systems. Limnol Oceanogr 36:1078-1090

Berman T, Holm-Hansen O (1974) Release of photoassimilated carbon as dissolved organic matter by marine phytoplankton. Mar Biol 28:305-310

Bjørnsen PK (1988) Phytoplankton exudation of organic matter: why do healthy cells do it? Limnol Oceanogr 33: 151-154

Blight SP, Bentley TL, Lefevre D, Robinson C, Rodrigues R, Rowlands J, Williams PJleB (1995) Phasing of autotrophic and heterotrophic plankton metabolism in a temperate coastal ecosystem. Mar Ecol Prog Ser 128:61-75

Bode A, Barquero S, Varela M, Braun JG, de Armas D (2001) Pelagic bacteria and phytoplankton in oceanic waters near the Canary Islands in summer. Mar Ecol Prog Ser 209:1-17

Bory AJM, Newton PP (2000) Transport of airborne lithogenic material down through the water column in two contrasting regions of the eastern subtropical North Atlantic Ocean. Global Biogeochem Cycles 14:297-315

Bratbak G, Heldal M, Norland S, Thingstad TF (1990) Viruses as partners in spring bloom microbial trophodynamics. Appl Environ Microbiol 56:1400-1405

Brussaard CPD, Riegman R, Noordeloos AAM, Cadée GC and 5 others (1995) Effects of grazing, sedimentation and phytoplankton cell lysis on the structure of a coastal pelagic food web. Mar Ecol Prog Ser 123:259-271

Bushaw KL, Zepp RG, Tarr MA, Schulz-Janders D and 5 others (1996) Photochemical release of biologically available nitrogen from aquatic dissolved organic matter. Nature 381:404-407

Carlson CA, Ducklow HW (1996) Growth of bacterioplankton and consumption of dissolved organic carbon in the Sargasso Sea. Aquat Microb Ecol 10:69-85

Carlson CA, Ducklow HW, Michaels AF (1994) Annual flux of dissolved organic carbon from the euphotic zone in the northwestern Sargasso Sea. Nature 371:405-408

Carlson CA, Ducklow HW, Sleeter TD (1996) Stocks and dynamics of bacterioplankton in the northwestern Sargasso Sea. Deep-Sea Res Part II 43:491-515

Choi CI (1972) Primary production and release of dissolved organic carbon from phytoplankton in the western North Atlantic Ocean. Deep-Sea Res 19:731-735

Christian JR, Karl DM (1994) Microbial community structure at the US-JGOFS Station ALOHA: inverse methods for estimating biochemical indicator ratios. J Geophys Res 99: 14269-14276

Cornell S, Rendell A, Jickells T (1995) Atmospheric inputs of dissolved organic nitrogen to the oceans. Nature 376:243-246

del Giorgio PA, Cole JJ (1998) Bacterial growth efficiency in natural aquatic systems. Annu Rev Ecol Syst 29:503-541

del Giorgio PA, Cole JJ (2000) Bacterial energetics and growth efficiency. In: Kirchman DL (ed) Microbial ecology of the oceans. Wiley-Liss, New York, p 289-326

del Giorgio PA, Cole JJ, Cimbleris A (1997) Respiration rates in bacteria exceed phytoplankton production in unproductive aquatic systems. Nature 385:148-151

Doval MD, Álvarez-Salgado XA, Pérez FF (2001) Organic matter distributions in the eastern North Atlantic-Azores front region. J Mar Syst 30:33-49

Duarte CM, Agustí S (1998) The $\mathrm{CO}_{2}$ balance of unproductive aquatic ecosystems. Science 281:234-236 
Duarte CM, Agustí S, del Giorgio PA, Cole JJ (1999) Regional carbon imbalances in the ocean. Response Sci 284:1735b

Duarte CM, Agustí S, Arístegui J, González N, Anadón R (2001) Evidence for a heterotrophic subtropical northeast Atlantic. Limnol Oceanogr 46:425-428

Ducklow HW (1993) Bacterioplankton distributions and production in the northwestern Indian Ocean and Gulf of Oman, September 1986. Deep-Sea Res Part II 40:753-771

Ducklow HW (2000) Bacterial production and biomass in the oceans. In: Kirchman DL (ed) Microbial ecology of the oceans. Wiley-Liss, New York, p 85-120

Ducklow HW, Carlson CA (1992) Oceanic bacterial production. Adv Microb Ecol 12:113-181

Fernández E, Pingree RD (1996) Coupling between physical and biological fields in the North Atlantic subtropical front southeast of the Azores. Deep-Sea Res Part I 43:1369-1393

Ferrier-Pagès C, Karner M, Rassoulzadegan F (1998) Release of dissolved amino acids by flagellates and ciliates grazing on bacteria. Oceanol Acta 21:485-494

Fogg GE (1983) The ecological significance of extracellular products of phytoplankton photosynthesis. Bot Mar 26:3-14

Frazel DW, Berberian G (1990) Distributions of chlorophyll and primary productivity in relation to water column structure in the eastern North Atlantic Ocean. Global Biogeochem Cycles 4:241-251

Fuhrman JA, Azam F (1980) Bacterioplankton secondary production estimates for coastal waters of British Columbia, Antarctica, and California. Appl Environ Microbiol 39: 1085-1095

Fuhrman JA, Azam F (1982) Thymidine incorporation as a measure of heterotrophic bacterioplankton production in marine surface waters: evaluation and field results. Mar Biol 66:109-120

Fuhrman JA, Noble RT (1995) Viruses and protists cause similar bacterial mortality in coastal seawater. Limnol Oceanogr 40:1236-1242

Fukuda R, Ogawa H, Nagata T, Koike I (1998) Direct determination of carbon and nitrogen contents of natural bacterial assemblages in marine environments. Appl Environ Microbiol 64:3352-3358

Gaines G, Elbrächter M (1987) Heterotrophic nutrition. In: Taylor FJR (ed) The biology of dinoflagellates. Blackwell Science, Oxford, p 224-269

Gasol JM, Morán XAG (1999) Effects of filtration on bacterial activity and picoplankton community structure as assessed by flow cytometry. Aquat Microb Ecol 16:251-264

Gobler CJ, Hutchins DA, Fisher NS, Cosper EM, Sañudo-Wilhelmy SA (1997) Release and bioavailability of C, N, P, Se and Fe following viral lysis of a marine chrysophyte. Limnol Oceanogr 42:1492-1504

González N, Anadón R, Mouriño B, Fernández E, Sinha B, Escánez J, de Armas D (2001) The metabolic balance of the planktonic community in the North Atlantic Subtropical Gyre: the role of mesoscale instabilities. Limnol Oceanogr 46:946-952

Gould WJ (1985) Physical oceanography of the Azores front. Prog Oceanogr 14:167-190

Hansell DA, Carlson CA (1998) Net community production of dissolved organic carbon. Global Biogeochem Cycles 12: 443-453

Hansell DA, Bates NR, Gundersen K (1995) Mineralization of dissolved organic carbon in the Sargasso Sea. Mar Chem 51:201-212

Harrison WG, Arístegui J, Head EJH, Li WKW, Longhurst AR, Sameoto DD (2001) Basin-scale variability in plankton biomass and community metabolism in the subtropical North Atlantic Ocean. Deep-Sea Res II 48:2241-2269
Hillebrand H, Dürselen CD, Kirschtel D, Pollingher U, Zohary $\mathrm{T}$ (1999) Biovolume calculation for pelagic and benthic microalgae. J Phycol 35:403-424

Hoppe HG, Gocke K, Koppe R, Begler C (2002) Bacterial growth and primary production along a north-south transect of the Atlantic Ocean. Nature 416:168-171

Jochem F, Zeitzschel B (1993) productivity regime and phytoplankton size structure in the tropical and subtropical North Atlantic in spring 1989. Deep-Sea Res Part I 96: 7083-7088

Joint I, Pomroy A, Savidge G, Boyd P (1993) Size-fractionated primary productivity in the northeast Atlantic in May-July 1989. Deep Sea Res Part II 40:423-440

Jumars PA, Penry DL, Baross JA, Perry MJ, Frost BW (1989) Closing the microbial loop: dissolved carbon pathway to heterotrophic bacteria from incomplete ingestion, digestion and absorption in animals. Deep-Sea Res 36:483-495

Karl DM, Hebel DV, Björkman K, Letelier RM (1998) The role of dissolved organic matter release in the productivity of the oligotrophic North Pacific Ocean. Limnol Oceanogr 43:1270-1286

Kiørboe T (1993) Turbulence, phytoplankton cell size, and the structure of pelagic food webs. Adv Mar Biol 29:1-72

Kirchman DL (1990) Limitation of bacterial growth by dissolved organic matter in the subarctic Pacific. Mar Ecol Prog Ser 62:47-54

Kuipers BR, Witte HJ (2000) Prochlorophytes as secondary prey for heterotrophic nanoflagellates in the deep chlorophyll maximum layer of the (sub)tropical North Atlantic. Mar Ecol Prog Ser 204:53-63

Kuipers BR, van Noort GJ, Vosjan J, Herndl GJ (2000) Diel periodicity of bacterioplankton in the euphotic zone of the subtropical Atlantic Ocean. Mar Ecol Prog Ser 201:13-25

Lancelot C, Billen G (1984) Activity of heterotrophic bacteria and its coupling to primary production during the spring phytoplankton bloom in the southern bight of the North Sea. Limnol Oceanogr 29:721-730

Legendre L, Le Fèvre J (1989) Hydrodynamical singularities as controls of recycled versus export production in oceans. In: Berger WH, Smetacek VS, Wefer G (eds) Productivity of the ocean: present and past. Wiley \& Sons, Chichester, p 49-63

Legendre L, Le Fèvre J (1995) Microbial food webs and the export of biogenic carbon in oceans. Aquat Microb Ecol 9: 69-77

Legendre L, Rassoulzadegan F (1995) Plankton and nutrient dynamics in marine waters. Ophelia 41:153-172

Lessard EJ, Swift E (1986) Dinoflagellates from the North Atlantic classified as phototrophic or heterotrophic by epifluorescence microscopy. J Plankton Res 8:1209-1215

Longhurst A (1998) Ecological geography of the sea. Academic Press, San Diego

Mague TH, Friberg E, Hughes DJ, Morris I (1980) Extracellular release of carbon by marine phytoplankton; a physiological approach. Limnol Oceanogr 25:262-279

Marañón E, Holligan PM, Varela M, Mouriño B, Bale AJ (2000) Basin-scale variability of phytoplankton biomass, production and growth in the Atlantic Ocean. Deep-Sea Res Part I 47:825-857

Menden-Deuer S, Lessard EJ (2000) Carbon to volume relationship for dinoflagellates, diatoms and other protist plankton. Limnol Oceanogr 45:569-579

Mopper K, Zhou X, Kieber RJ, Kieber DJ, Sikorski RJ, Jones RD (1991) Photochemical degradation of dissolved organic carbon and its impact on the oceanic carbon cycle. Nature 353:60-62

Moran MA, Zepp RG (2000) UV radiation effects on microbes 
and microbial processes. In: Kirchman DL (ed) Microbial ecology of the oceans. Wiley-Liss, New York, p 201-228

Morán XAG, Gasol JM, Arin L, Estrada M (1999) A comparison between glass fiber and membrane filters for the estimation of phytoplankton POC and DOC production. Mar Ecol Prog Ser 187:31-41

Morán XAG, Gasol JM, Pedrós-Alió C, Estrada M (2001) Dissolved and particulate primary production and bacterial production in offshore Antarctic waters during austral summer: coupled or uncoupled? Mar Ecol Prog Ser 222: 25-39

Nagata T (2000) production mechanisms of dissolved organic matter. In: Kirchman DL (ed) Microbial ecology of the oceans. Wiley-Liss, New York, p 121-152

Nagata T, Kirchman DL (1992) Release of dissolved organic matter by heterotrophic protozoa: implications for microbial food webs. Ergeb Limnol 35:99-109

Panzenböck M, Möbes-Hansen B, Albert R, Herndl GJ (2000) Dynamics of phyto- and bacterioplankton in a high Arctic lake on Franz Joseph Land archipelago. Mar Ecol Prog Ser 21:265-273

Pérez FF, Gil-Coto M, Ríos AF (2003) Large and mesoscale variability of the water masses and the deep chlorophyll maximum in the Azores Front. J Geophys Res (in press)

Porter KG, Feig YS (1980) The use of DAPI for identifying and counting aquatic microflora. Limnol Oceanogr 25:943-948

Putt M, Stoecker DK (1989) An experimentally determined carbon:volume ratio for marine 'oligotrichous' ciliates from estuarine and coastal waters. Limnol Oceanogr 34: 1097-1103

Quevedo M, Anadón R (2001) Protist control of phytoplankton growth in the subtropical north-east Atlantic. Mar Ecol Prog Ser 221:29-38

Rivkin RB, Legendre L (2002) Biogenic carbon cycling in the upper ocean: effects of microbial respiration. Science 291: $2398-2400$

Robinson C, Serret P, Tilstone G, Teira E, Zubkov MV, Rees AP, Woodward MS (2002) Plankton respiration in the Eastern Atlantic Ocean. Deep-Sea Res Part I 49:787-813

Serret P, Fernández E, Sostres JA, Anadón R (1999) Seasonal compensation of microbial production and respiration in a temperate sea. Mar Ecol Prog Ser 187:43-57

Serret P, Robinson C, Fernández E, Teira E, Tilstone G (2001) Latitudinal variation of the balance between plankton photosynthesis and respiration in the eastern Atlantic Ocean. Limnol Oceanogr 46:1642-1652

Sherr EB, Sherr BF (1996) Temporal offset in oceanic production and respiration processes implied by seasonal changes in atmospheric oxygen: the role of heterotrophic microbes. Aquat Microb Ecol 11:91-100

Editorial responsibility: Otto Kinne (Editor),

Oldendorf/Luhe, Germany
Sieracki ME, Haugen EM, Cucci TL (1995) Overestimation of heterotrophic bacteria in the Sargasso Sea: direct evidence by flow and imaging cytometry. Deep-Sea Res 42 : 1399-1409

Søndergaard M, Hansen B, Markager S (1995) Dynamics of dissolved organic carbon lability in a eutrophic lake. Limnol Oceanogr 40:46-54

Stoderegger K, Herndl GJ (1998) Production and release of bacterial capsular material and its subsequent utilisation by marine bacterioplankton. Limnol Oceanogr 43:877-884

Straskraba M, Gnauck AH (1985) Freshwater ecosystems: modelling and simulation. Elsevier, Amsterdam

Teira E, Serret P, Fernández E (2001a) Phytoplankton sizestructure, particulate and dissolved organic carbon production and oxygen fluxes through microbial communities in the NW Iberian coastal transition zone. Mar Ecol Prog Ser 219:65-83

Teira E, Pazó MJ, Serret P, Fernández E (2001b) Dissolved organic carbon (DOC) production by microbial populations in the Atlantic Ocean. Limnol Oceanogr 46:1370-1377

Thingstad TF (2000) Elements of a theory for the mechanisms controlling abundance, diversity, and biogeochemical role of lytic bacterial viruses in aquatic systems. Limnol Oceanogr 45:1320-1328

Thomas JP (1971) Release of dissolved organic matter from natural populations of marine phytoplankton. Mar Biol 11: 311-323

Willey JD, Kieber RJ, Eyman MS, Avery GB (2000) Rainwater dissolved organic carbon: concentrations and global flux. Global Biogeochem Cycles 14:139-148

Williams PJleB (2000) Heterotrophic bacteria and dynamics of dissolved organic material. In: Kirchman DL (ed) Microbial ecology of the oceans. Wiley-Liss, New York, p 153-200

Williams PJleB, Yentsch CS (1976) An examination of photosynthetic production, excretion of photosynthetic products, and heterotrophic utilization of dissolved organic compounds with reference to results from a coastal subtropical sea. Mar Biol 35:31-40

Yamanaka Y, Tajika E (1997) Role of dissolved organic matter in the marine biogeochemical cycle: studies using an ocean biogeochemical general circulation model. Global Biogeochem Cycles 11:599-612

Zubkov MV, Sleigh MA, Tarran GA, Burkill PH, Leakey RJG (1998) Picoplanktonic community structure on an Atlantic transect from $50^{\circ} \mathrm{N}$ to $50^{\circ} \mathrm{S}$. Deep-Sea Res Part I 45: $1339-1355$

Zubkov MV, Sleigh MA, Burkill PH, Leakey RJG (2000) Bacterial growth and grazing loss in contrasting areas of North and South Atlantic. J Plankton Res 22:685-711

Submitted: July 17, 2002; Accepted: December 17, 2002

Proofs received from author(s): February 14, 2003 